\title{
Expressing physical and emotional state changes through the verb get and its translations in bilingual writing, English-Spanish, in high school
}

\begin{abstract}
This article characterizes high school students' performance, in the mediatheque of languages, in English-Spanish bilingual writing of short narratives texts with the verb get and its translation to express health and emotions state changes. These meanings involve multifunctional and polisemic criteria in the lexical and semantic selections in both languages and morphology with prefixes and circunfixes in Spanish. Methodology contemplates a teaching activity related to state change meaning, a partially guided exercise to promote bilingual narrative writing, feedback and revision to write an improved version. With the approach of functional characterization of verbal resources, the research includes analysis categories focused in intentionality and self-translation practices. The results show students' attempts to express the semantic trait of the beginning or transition of the state change through verbal phrases with the verb get and its translation into Spanish, as well as difficulties in both languages. The article provides conceptual and methodological criteria for the study of verbal expressions and their semantic features in bilingual writing.
\end{abstract}

Keywords: get, bilingual writing, state changes, semantic feature, intentionality
Volume 2 Issue 5 - 2018

\author{
Ernesto Hernández Rodríguez \\ Doctor in Linguistics, Universidad Nacional Autónoma de \\ México, Mexico \\ Correspondence: Ernesto Hernández Rodríguez, Doctor \\ in Linguistics, Universidad Nacionall Autónoma de México, \\ Emiliano Zapata 18, Guadalupe Victoria Cuautepec, 07209 \\ Ciudad de México, México, Tel: 0445527454505 , \\ Email ernestotem@live.com.mx
}

Received: September 27, 2018 | Published: October 03, 2018

\section{Introduction}

Bilingual, English-Spanish, writing constitutes a useful practice for learning native (L1) and foreign languages, in this case, with verbs that express physical and emotional change. In this perspective, L1 and L2 coexist because they are both susceptible to learning in different areas and levels. ${ }^{1}$ This practice promotes regulation of intentionality in performance, ${ }^{2-5}$ contrast analysis and adjustment of expressions in both languages and reflexive self-translation to achieve bilingual writing: Francis \& Hamel; Francis; Spicer-Escalante. ${ }^{6-8}$ High school students' knowledge and performance of English as a foreign language, about usages of verb get involves considering its polisemic and multifunctional nature and its manifestation in phrases by means of certain lexical and sintagmatic selections. ${ }^{9-14}$ Translation to Spanish also involve parenthetical morphological options with prefixes and circunfixes; Zacarías Ponce de León 2016, ${ }^{15}$ for example, the translation of the condition states bad- worse "mal - peor" corresponds to get worse "ponerse mal, em-peor- ar o ponerse peor". Thus, the bilingual manifestation of these meanings is related to the integral usage of lexical, semantical and morphological selections. ${ }^{12}$

In the approach of functional characterization of verbal resources in textual linguistics, this paper studies bilingual, English-Spanish, writing of narrative texts in which the verb get appears, and its translation options to express state changes. This paper considers the characterization of bilingual written intentionality performance. The next sections present the objectives, justification, the proposal of bilingual writing in scholar contexts and the conceptual considerations about verbal expressions in English and Spanish, related to physical state changes in health and emotions involved. The study continues with the students' characterization in the extracurricular workshop about verbal usages, teaching methodology in the exercise designed, and interactions experienced. Result section presents classification and analysis categories according to intentionality criteria in usages and lexical, semantical and morphological alternances to express state changes in bilingual versions. Conclusions highlight alternances to express state changes and the decisions to solve difficulties and intentionality in bilingual written performance.

\section{Objective}

The purpose of this research is the descriptive characterization of intentionality in the performance of foreign language high school students in bilingual writing, English-Spanish, of short narrative texts, with the verb get and its translation options to Spanish with the change of state meanings related to health and the corresponding emotions associated. The activities involve adjusting and regulating bilingual writing by means of contrastive revision of languages, self-translation in guided and feed backed practices in the mediatheque of languages and the attempts to write an improved version in both languages. The justification for this research is related to the importance of promoting development and integral performance improvement of native and foreign languages in contextualized learning writing activities and reflexive self-translation in bilingual writing. In this way, it is possible to consider learning objectives and both language enrichment. The proposal allows studying verbal resources in written practical situations and avoiding language decontextualization. Moreover, the proposal promotes performance and intentionality reflection.

\section{Approach}

This paper considers intentionality characterization and performance regulation in bilingual, English-Spanish, writing of short narrative texts, with the verb get and its translations options to express physical state changes related to health and appearance and the emotions involved. In this written practice, native and foreign languages coexist with learning objectives and self-translation resources. 


\section{Intentionality and bilingual writing}

The study of performance intentionality in bilingual writing allows considering whatever students try to express, the way they face difficulties, options and writing decisions to try to achieve communicative purposes. ${ }^{4}$ In this approach, it is fundamental to contemplate interpretation when considering that a text "supposes an author, as well as a reader or interpreter, who is going to interpret it. There is, on the one hand, an authors' intention, about what he tried to express in the text; and there is, on the other hand, a reader's intentionality, which not always interprets what the author pretended to be understood, but incorporates personal meanings. ${ }^{\mathrm{i}, 5}$ In this perspective, students return to their texts to try to achieve the communicative purpose in self-regulation practices of linguistic performance ${ }^{2}$ and compensatory strategies ${ }^{16,17}$ to try to express clearly the state of change meaning, for example, when an expression is clear in one language, but not in the other. In bilingual teaching, Duverger (2009 y 2011) and Geiger-Jaillet, Schlemminger \& Le Pape Racine (2011) consider L1 and L2 coexistence in class, according to specific learning objectives. The proposal contemplates language alternances to learn subject contents and bilingual communication. Thus, in interaction, the teacher determines the convenient moments for certain language in order to fulfill linguistic and disciplinary objectives.

From this conception, this research assumes that bilingual writing favors development of textual abilities and knowledges related to foreign language for specific objectives and native language improvement in self-translation practices. As background approach references, Francis \& Hamel (1992) and ${ }^{10}$ study elementary indigenous bilingual students' writing in Spanish, Otomí and Náhuatl in México. In researches related to writing in English and Spanish, Spicer-Escalante (2007) analyses performances of Spanish native speakers migrants in United States, Freman \& Freeman (2006) study difficulties resolutions and Hernández Rodríguez (2015) characterizes intentionality in bilingual writing. Bilingual writing for specific learning goals, for example, verbal usage to express physical and emotional state changes enables us to contemplate dynamic translation proposals to rewrite, correct and enrich the original text. ${ }^{18-}$ ${ }^{20}$ Pegenaute $^{21}$ conceives translation as a useful rewriting exercise "at the moment of understanding better not only the functioning of L2, but also of L1" (p.115) $)^{\mathrm{ii}}$ and $\mathrm{d}^{22}$ highlights metalinguistic reflections about contrastive differences and similarities in both languages.

As a theoretical background of self-translation in bilingual writing, this work contemplates the writing of students' own texts in another language, as a variant of translation, ${ }^{23}$ linguistic and contextual environment, ${ }^{24}$ discussions about the original and translated text ${ }^{25}$ and theoretical and practical considerations in scholar and academic self-translation. ${ }^{26}$ Bilingual writing involves performing contrastive language revision practices, ${ }^{27-30}$ determining textual decisions for selftranslation and solving difficulties faced. To do this, it is necessary to modify writing to improve it, and adjust expressions in both languages. In this perspective, translation is not exclusive to the experts; students can experience it as an exercise in linguistic and disciplinar learning.

iOriginal quotation: "supone un autor, así como un lector o intérprete, que es quien lo va a interpretar. Hay, por un lado, una intención del autor, que es lo que quiso expresar en su texto; y hay otra intencionalidad, la del lector, que no siempre interpreta lo que el autor quiso que se entendiera, sino que añade significados propios" (Beuchot, 2015: 129).

iiOriginal quotation: "a la hora de entender mejor el funcionamiento no sólo de L2 sino también de L1"

\section{Semantic features associated with the change of state}

This research contemplates the approach of semantic features, associated to the linguistic units, and their impacts in the conformation of the syntagmatic structure and of lexical and morphological selections. The change of a state constitutes a fundamental semantic feature related to other semantic values in certain uses and structures, that is, it is activated in certain lexical or morphological selections, in such a way that "each word updates a meaning, whether basic or metaphorical, in discourse as a function of the lexical pieces that accompany it. [...] This significant difference lies in the internal structure of the meaning of a word, consisting of a series of abstract minor features that intervene in a wide variety of meaningful connections with other words; traits that are activated in one combination do not activate in another. ${ }^{\mathrm{iii}, 31}$ Studies on this topic consider verbal meanings related to the characteristics of the state change studied, that is, distinctive features associated, for example, with inchoativity to refer to the beginning of the change, ${ }^{32}$ aspectuality for the duration or process, ${ }^{33}$ causation $^{34}$ and movement and location. ${ }^{35}$ About the verb get, Fernández Guerra (2001a) highlights the variety of semantic values and communicative functions.

The verb is the proposition and grammatical category that expresses a predicate about a subject, which can be personal, impersonal, explicit or implicit. The verb is not limited only to actions, since, in addition, it can manifest "changes, movements of beings or things, [...] the activities carried out or suffered by people and animals, as well as situations or states in which they are, the changes that the objects suffer, the manifestations of diverse phenomena of the nature". ${ }^{\mathrm{i}, 36}$ In particular, state changes are fundamental meanings of the verb and there are various resources to express them through lexical, semantic and morphological selections in bilingual expression, English-Spanish. In this conception, we can consider approaches on the influence of state change meaning in the linguistic structure at the lexical level, ${ }^{37}$ in verbal phrases ${ }^{38}$ and in certain morphological processes. $^{15}$

\section{Bilingual expression of state change: verb get and its translations}

In English, the verb get has polysemic and multifunctional properties. ${ }^{39}$ To express state changes, its use corresponds to a paradigm related to lexical, semantic and syntagmatic selections related to certain words or phrases. ${ }^{13}$ Also, in translation practices cultural referents are involved in the expression meanings in certain

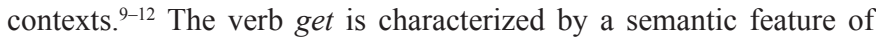
state change, fundamentally, expressed with adjectives and nouns, with different nuances of meaning. ${ }^{11}$ We can notice this situation, for example, in movement in I got late "llegué tarde", in a voluntary act in I got married, "me casé", in the involuntary situation of health in $I$

\footnotetext{
iii Original quotation: "cada palabra actualiza una acepción - un significado, ya sea el básico o el metafórico, en el discurso en función de las piezas léxicas que la acompañan.[...] Esta diferencia significativa radica en la estructura interna del significado de una palabra, conformada por una serie de rasgos menores abstractos que intervienen en una gran variedad de conexiones significativas con otras palabras; los rasgos que se activan en una combinación no se activan en otra" (Sánchez Rufat, 2014).

iv Original quotation: "cambios, movimientos de seres o cosas, [...] las actividades que realizan o padecen las personas y animales, así como las situaciones o estados en que éstos se encuentran, los cambios que sufren los objetos, las manifestaciones de diversos fenómenos de la naturaleza" (Munguía Zatarín, Munguía Zatarán \& Rocha Romero, 2002)
} 
got sick "me enfermé", in the passive form I got fired"fui despedido" in the situation of receiving and getting something in I got good news "recibí buenas noticias" and I got a new job "conseguí un nuevo empleo", as well as in the causative expression I got her to help me "hice que ella me ayudara". In bilingual expression, English-Spanish, we can notice different resources in the translation of the verb get to express the transition from one state to another. ${ }^{10}$ In particular, this research focuses on the meanings corresponding to the physical aspect of health and emotions involved. In this way, the verb get sick "enfermarse" is related to the get worse state and its translation options "empeorar" or "ponerse peor", to express an involuntary change to another unfavorable situation. In the health situation, we can associate a state of emotion, for example, get depressed "deprimirse" or get sad "entristecerse". Similarly, the physical change get strong "fortalecerse" or get attractive "ponerse atractivo" can relate to a state of emotion, for example, the verb get happy "alegrarse".

In English, these uses appear in fixed structures or specific lexical collocations that, together, correspond to a matrix of semantic features related to the beginning or the process of the state change, voluntary or involuntary situation, inchoative or procedural involuntary. The verbal phrase can include adjectives (get nervous "ponerse nervioso"), participles (get tired "cansarse") and nouns (get a fever "tener fiebre"), as well as other phrases (get in a bad mood "ponerse de mal humor ", get over "recuperarse", get out of "salir o liberarse de").

Lexical resource: get.

get + [expression associated with the state or situation]

Semantic features: physical health change, change of mood, voluntary or involuntary situation, inchoative or procedural,

This expression of state change coexists with others, for example, get/fall in love "enamorarse", get/become crazy "volverse loco". Also, it presents restrictions of structural lexical collocations, for that reason certain expressions are ambiguous or not used, for example, "convertirse o volverse malo, "héroe", "presidente": * get bad: * get hero, * get president. Lexical selections require considering the restrictions of semantic and pragmatic usages. For bilingual expression, translation into Spanish requires considering lexical or morphological expressions that accompany the verb, corresponding to semantic features in certain syntagmatic distributions and lexicoverbal collocations, with different nuances of meaning. Likewise, the meaning of the state implies the change experienced in an inchoative way, that is, the beginning of the transition, the process or the effect produced. ${ }^{40}$ We can appreciate this distinction, for example, in get angry "enojarse" be angry "estar enojado". Contrastive analysis of state change verbs in both languages involves the options of lexical selection with the verb get, and, in Spanish, the lexical resource with the verb poner "put", in reflexive form ${ }^{28-30}$ and prefixes and circumfixes morphology. ${ }^{15}$

Lexical resource: poner "put"

poner-Reflexive pronoun + [expression associated with the state or situation]

Semantic features: physical health change, change of mood, voluntary or involuntary situation, inchoative or procedural

For example, with the verbs get fit "ponerse en forma" and get drunk "emborracharse or ponerse borracho", we express physical state change, related to the semantic features of voluntary act during a process. On the other hand, the verb get surprised "sorprenderse", emphasizes involuntary change and inchoativity, which is the precise moment of the transition or the beginning of the corresponding state. In Spanish, we have the option of the parasynthetic morphological resource with the circumfix consisting of the affixations $a$-, en-lemand the options of derivative suffixing by infinitive and the suffix -ecer, predominantly, inchoative, accompanied by the reflexive pronoun, prefixed to the conjugated verb.

\section{Parasynthetical morphological resource}

Prefix a-, en- / em- [expression associated with the state] Derivative suffix-Reflexive pronoun

Semantic features: physical change (health or appearance), change of mood, voluntary or involuntary situation, inchoative or procedural.

For example, the verbs get embarrased "avergonzarse" and get sad "entristecerse" express moods or emotions, susceptible of being controlled or decided voluntarily. In addition, they manifest, in an inchoative way, the beginning of the experienced change.

Embarrassment "vergüenza" "a-vergonz-ar-se" I got embarrased "Me avergoncé"

Sadness "tristeza" "en-trist-ecer-se" I got sad "Me entristecí"

(Inchoative and voluntary mood or emotion change)

In contrast, the semantic trait of involuntary state change, for example, get old "envejecer" and get crazy "enloquecer" lacks the reflexive pronoun, because a person only experiences this state and does nothing to get in such a situation. It is impossible to decide not to get older. The use of the reflexive pronoun is only an emphatic stylistic device.

Morphological derivative suffixation resource

[Expression associated with the state or situation] - Derivative suffix

Semantic features: physical health change, change of mood, voluntary or involuntary situation, inchoative or procedural

get old "envej-ecer" He got older "Él envejeció"

get pale "em-palid-ecer" She got pale "Ella em-palid-eció o se puso pálida" (involuntary and procedural physical change)

However, in the lexical resource the reflexive pronoun appears, for example, "Ella se puso pálida" She got pale. On the other hand, in Spanish we have the option of derivative suffixing by infinitive, and also by the suffix -ecer, in its processual or permanence meaning, accompanied by the reflexive pronoun. In addition, some expressions also accept the lexical resource by means of the verb poner.

Morphological derivative suffixation resource

[expression associated with the state or situation] - Derivative suffix - Reflexive pronoun

Semantic features: physical health change, change of mood, voluntary or involuntary situation, inchoative or procedural

\section{Example}

Get strong "fortal-ecer-se" I got stronger with exercise "Me fortalecí con el ejercicio" 
I got strong with exercise "Me puse fuerte con el ejercicio" (voluntary change of appearance and process)

In Spanish there are restrictions on selection and structural collocations, since some expressions only appear with the lexical resource. For example, get attractive "ponerse atractivo" does not accept the affixation to express the state change: * en-atractiv-arse. Certain verbs only accept morphological resources, for example, the translation of the verb get up in its reflexive manifestation, "levantar-se o incorporar-se". However, the lexical option of "ponerse levantado o incorporado" is kind of weird to describe health improvement. Sometimes the translation involves semantic nuances that require contextualizing for the desired meaning. For example, the translation of get crazy by the lexical resourse "ponerse" corresponds to a colloquial use of emotional alteration, while the parasynthetic morphological option "en-loqu-ecer" is associated with losing mind capacities "perder la razón", apparently closer to get insane. In get crazy and its possible translations "enloquecer" versus "ponerse loco", we have the following semantic features: madness, health and emotion, inchoative and gradual or permanent process, and, to the extent that we may control emotions, involuntary and voluntary. Due to the previous considerations, to study state change, expressed with the verb get and its options of translation in bilingual, English-Spanish, writing, it is fundamental to characterize intentionality and regulation in linguistic performance and also contrastive considerations in the decisions related to the lexical and morphological selection, since there are multiple possibilities in self-translation practices.

\section{About the students participating in the verbal usages workshop}

In this research, teenager students of English as a foreign language, from Escuela Nacional Preparatoria Justo Sierra in Mexico City, participated. The students attended the extracurricular workshop on verbal uses in the mediatheque of languages. This academic space is dedicated to promoting and strengthening language learning in the self-regulation perspective with the support of advisors.

The students had previously studied units 4 and 5 of the second cycle, corresponding to uses and functions of the verb get. This program includes grammatical topics, predominantly, in writing and reading comprehension exercises. ${ }^{41}$ The performance of the students was variable because they came from different groups and levels in language skills. Due to the different performances in oral expression and comprehension, and also the interest in this research for written expression, the language of instruction was Spanish. The purpose of the workshop was to encourage bilingual writing, English-Spanish, of brief narrative passages where the verb get and its translation options were used to express the meaning of changes in physical health and emotion states. It was essential to rewrite the texts to try an improved version through the contrastive revision of the languages, regulation of performance and intentionality in self-translation practices in bilingual writing.

\section{Methodology}

The methodology contemplated an activity to remember the contents in the courses related to the use of the verb get to express state change and its possibilities of translation into Spanish. Likewise, it included the methodological techniques of partially guided elicitation ${ }^{42,43}$ to obtain the data and representative samples of bilingual writing. By exposing verbal uses with this meaning, we contrasted the ways of expressing it in both languages. Through a brainstorm, we provided representative examples of bilingual expressions, English-
Spanish, to express physical health and emotion states. The students then performed a bilingual, partially guided writing exercise to write bilingual narrative passages on physical health changes and wrote down the emotion due to the change experienced. In the first part, students observed a story in images, related with verbal phrases about changes in physical state and emotion with the verb get. ${ }^{\mathrm{v}}$ When finished, they made comments with their advisor. Through this practice, the students conceived and organized the narrative of the story. In the second part, they translated the verbs included in the story in images: get wet, get cold, get sick, get a fever, get a cold, get pale, get worse / get sad, get depressed, get upset, get disappointed and get frustrated. For this task, they had the possibility to rely on the Resource manual for bilingual writing ${ }^{44}$ and indicate the source consulted. This material provides a menu of texts and online support programs: dictionaries and translators, grammar texts, spelling, programs for textual revision and correctors in the word processor. ${ }^{\mathrm{vi}}$ This exercise allowed the students to have elements of support to carry out the corresponding translation. In addition, students had the possibility to freely write other examples of the verb get to express state changes. In the third section, the students read a bilingual fragment, English-Spanish, of the story in images, and then completed it, using the translated verbs. In addition, they were able to use other expressions of the state change and their translations. Finally, the students reviewed their writings to modify them with the idea of writing an improved version based on the observations and suggestions of the advisor and the support of the Resource Manual for bilingual writing. This practice allowed the students to regulate their performances in the contrastive revision of the languages and the intentionality in writing and self-translation decisions.

\section{Results and discussion}

\section{Bilingual identification of state change meanings}

Results show that in the translating exercise of the considered verbs, students identified health and emotional state change in two characteristics: inchoative value corresponding to the beginning or transition of the change involved, for example, get sad "ponerse triste" or "entristecerse", and the permanence or procedure of that state, for example when translating get sad as "estar triste" (be sad) or get depressed as "estar deprimido" (be depressed) ) $^{32}$ and $^{33}$ the distinction between the beginning or transition of a state change, in contrast with its permanence. Table 1 exhibits the permanence of state trait predominance through the verb get in students' translations. Also, the coexistence of this trait with the inchoative one indicates the tendency to consider both meanings without distinction. The numbers in parenthesis are associated to each student and the identification of the texts involves the following code: $t$ : text, f: female, m: male and the number assigned.

The following examples show the three representative kinds of performances in the translations. Student $t 1 \mathrm{f}$ expressed the inchoative meaning by means of the lexical option (example: get sad "ponerse triste") and the morphological (examples: get cold "en-friar-se" and get upset "enfadar-se). In t19f, the translation of get cold, indeed, corresponds to the permanence state trait: be cold "estar frío". In t6f, the combination of this semantic values in the translations includes inchoative morphological expressions (example: get sick "enfermar-

"The exercise can be retrieved from (Hernández Rodríguez (2005). https:// drive.google.com/file/d/1aoyI1TDd9Rb5ErH-i8pZp7cQLjsTQ9DN/view viThe document can be retrieved from Hernández Rodríguez \& Reyes Galicia (2015). https://issuu.com/asesormediatecaprepa3/docs/recursos_para taducir ingl $\mathrm{s}$ y co 
se", get cold "en-friar-se" and the lexical expressions estar and tener for the state permanence trait: get pale, translated by the student as "estar pálido" and get depressed as "tener depresión".

Table I State change semantic traits

\begin{tabular}{ll}
\hline State change semantic traits & $\begin{array}{l}\text { Predominant translations (25 } \\
\text { students) }\end{array}$ \\
Inchoative (beginning or transition) & $7(1,3,12,15,20,23,24)$ \\
Permanence & $10(4,5,8,9,13,16,17,18,19,21)$ \\
Both (inchoative or permanence) & $8(2,6,7,10,11,14,22,25)$ \\
\hline
\end{tabular}

Examples of representative translations

\begin{tabular}{|c|c|c|c|}
\hline verb & tlf: inchoative & tl9f: permanence & t6f: both \\
\hline Get wet & mojarse & Estar mojado & mojarse \\
\hline Get cold & enfriarse & Estar frío & enfriarse \\
\hline Get sick & $\begin{array}{l}\text { Se puso } \\
\text { enfermo }\end{array}$ & Estar enfermo & enfermarse \\
\hline Get a cold & Resfriarse & Estar con frío & resfriarse \\
\hline Get pale & Ponerse pálido & Estar resfriado & Estar pálido \\
\hline Get sad & Ponerse triste & Estar triste & Estar triste \\
\hline Get depressed & Deprimirse & Estar depresivo & Tener depresión \\
\hline Get upset & enfadarse & Estar enfadado & Estar molesto \\
\hline Get frustrated & $\begin{array}{l}\text { Ponerse } \\
\text { frustrado }\end{array}$ & Estar frustrado & Estar frustrado \\
\hline
\end{tabular}

This situation is the evidence of the students' difficulties to recognize the semantic traits between the begining of the state change, for example, in the translation of get sad as "estar triste" (be sad). Table 2 presents the performance of the 24 students who said they knew other meanings of state change with the verb get and wrote them freely with their translations. The student $t 7 \mathrm{f}$ expressed that she didn't remembered other meanings. We can notice the predominance of the permanency trait (11) and its combined appearence with the inchoative semantic value (5). Furthermore, the difficulties in performance can be observed in the examples which are not related to health or emotional state change, for example, get up "levantarse", get "obtener" and in other incorrect usages, for example *get have "tener", *get jump "brincar". These results indicate that students had to identify the semantic traits related to beginning or transition and permanence of health and emotional state change and its semantic contextualized resignifications in certain usages..$^{31}$ For this purpose, it was necessary the contrastive analysis of resources in both languages ${ }^{27,28}$ in order to achieve the self-translation practice ${ }^{45,46}$ in scholar environment. ${ }^{26}$ The expression of state change was expressed in the lexical options ${ }^{28}$ and the morphological ones of suffixation and parasinthetical, ${ }^{47}$ and the following semantic state change traits: health, emotional, voluntary, involuntary, beginning and permanence. The students had to express in bilingual writing the beginning (get sad) or permanence (be sick) semantic state change traits

Table 2 State change semantic traits in examples provided by the students

\begin{tabular}{ll}
\hline $\begin{array}{l}\text { State change semantic } \\
\text { traits }\end{array}$ & $\begin{array}{l}\text { Predominant translations (24 } \\
\text { students) }\end{array}$ \\
\hline Inchoative & $4(2,22,23,24)$ \\
Permanence & II $(4,5,6,10,15,16,17,19,20,21,25)$
\end{tabular}

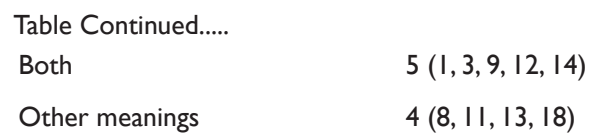

\section{Examples}

get sad: t3m: "en-trist-ecer-se" (parasinthetical morphology)

t7m: "ponerse triste" (lexical)

Semantic traits: [inchoative, emotional, involuntary]

be sad: $\mathrm{t} 8 \mathrm{~m}$ : "triste" sad (lexical)

t21: "estar triste" (lexical)

Semantic traits: [permanence, emotional, involuntary]

In the students' performances, they had to solve difficulties in the contrastive analysis, English-Spanish, to identify semantic traits and linguistic resources in each language. In this way, they could solve the confusions in meanings and translations, for example, between get sick "enfermarse" and get depressed "deprimirse", and, on ther other hand, be sick "estar enfermo" and be depressed "estar deprimido".

\section{Performance in translation with the aid of on-line dictionaries and translators}

The results show the problems in translating the meanings of the verb get to express state change with the aid of on-line dictionaries and translators. Table 3 exhibits the sources consulted and the difficulties in trying to translate exact meaning. Students consulted Cambridge, Oxford and Merriam online dictionaries and Google translator. viiThe data show the predominance of difficulties in translation. The consultations in monolingual dictionaries, English-English, and online Google translator were not favorable in students' translations. In the dictionaries, the students had to review the different lexical entries of the verb get and, also, the correct verbal phrases and meanings to express inchoative health and emotional state change. Therefore, they presented difficulties in identifying these aspects in the definitions of the dictionaries. For example, in t6f the student consulted the Oxford Dictionary and the Wordreference and, nevertheless, she could not express the beginning of the state change in her translation.

Table 3 On-line sources consulted

\begin{tabular}{lll}
\hline Sources consulted & $\mathbf{2 5}$ students & $\begin{array}{l}\text { Dificulties in } \\
\text { translation }(20 \\
\text { students) }\end{array}$ \\
\hline $\begin{array}{l}\text { English monolingual } \\
\text { dictionary }\end{array}$ & $\begin{array}{l}9(7,10,11,13,14,16, \\
17,18,20)\end{array}$ & $\begin{array}{l}8(10,11,13,14,16,18,24) \\
17,14,\end{array}$ \\
$\begin{array}{l}\text { Bilingual dictionary } \\
\text { Google translator }\end{array}$ & $3(6,8,9)$, & $3(6,8,9)$ \\
$\begin{array}{l}\text { Dictionary and } \\
\text { translator }\end{array}$ & $6(2,3,4,12,22,25)$ & $5(1,2,4,22,25)$ \\
None & $6(1,5,19,21,23,24)$ & $3(5,19,21)$ \\
\hline
\end{tabular}

t6f: get upset, translated as "estar enfadado" (be upset). Consultation in Wordreference

get pale, translated as "estar pálido" (be pale). Consultation in Oxford Dictionary.

In online translators, the students needed contextualization and contrastive revision, English-Spanish, to determine the adequate

viiThe links to the diccionaries can be retrieved from Hernández Rodríguez \& Reyes Galicia (2015). https://issuu.com/asesormediatecaprepa3/docs/ recursos_para_taducir_ingl_s_y_co 
lexical use of the translated phrase, since this tool is limited in these aspects. For example, the student t6f translated get disappointed, as "decepcionado", that is, according to the trait of permanence related to emotional state, due to the response obtained in the Google translator. In contrast, student $\mathrm{t} 12 \mathrm{~m}$ noticed this situation, and solved it by modifying the information provided by the online translator, using the morphological resource in his translation: get disappointed "decepcionarse". The students had to take into account the advantages and limitations of online translators, since for example, Google translator only provides one possibility of translation for state change meaning, be it the lexical, for example, get pale "ponerse pálido" or the morphological one, for example, get sad "entristecerse." Therefore, students needed to use translators as support tools that require contextualization with their linguistic knowledge and practice.

\section{General characterization of performance in bilingual writing}

The results show different difficulties faced by the students in bilingual writing: bilingual narrative use of the past tense verbs, spelling, lexical selections, graphical accentuation in Spanish and, mainly, ambiguities in the translation of the meaning of the beginning and permanence of state change. The performance of student $17 \mathrm{~m}$ is representative in the variety of problems faced, related to word selections and grammatical structuring, for example, in "no get upset to go the party, I got disapointed", "no tenía animo para ir a la fiesta, me puse en desacuerdo" and in the present and past tenses oscillation. In addition, he showed confusion in the translation to express the beginning of state change, for example, in the first version: no get upset "no tengo animo", I got sad "Estoy triste" and in the second version: no get upset "no tengo ánimo", I got sad, I was very dissillusioned "Estaba triste, estaba muy desilusionado". In the examples provided in this study, the transcription respects the writing, without spelling, graphic accentuation, grammar or word segmentation corrections.

\section{7m First version}

English: I got a fever, I'm very depressed, no get upset to go to the party, I got disappointed, i love play with my friends, this party is the best of the week and I'm no went I got sad. I 'm very disillusionned.

Spanish: Yo tuve fiebre, yo estoy muy deprimido, no tengo animo para ir a la fiesta, me puse en desacuerdo, yo amo jugar con mis amigos, esta fiesta es la mejor de la semana y no voy Estoy triste, estoy muy desilusionado.

\section{Second version}

English: I got a fever, I was very depressed, no get upset to go the party, I got disappointed, i love my friends, this party was the best of the week and I did no go I got sad, I was very disillusioned.

Spanish: Yo tuve fiebre, yo estoy muy deprimido, no tenía animo para ir a la fiesta, me puse en desacuerdo. yo amo jugar con mis amigos esta fiesta fue la mejor de la semana y no voy Estaba triste, estaba muy desilusionado

Table 4 shows the progress in bilingual writing performance in both versions, mainly, the use of past tense in English for narrative expression and graphical accentuation in Spanish. However, students experienced difficulties in expressing inchoative meaning to express state change. The study of both bilingual versions allows the characterizing of intentionality in students' performance. ${ }^{48}$ In the revision and textual edition it is fundamental to consider the decisions and strategies to try to improve the linguistic expression ${ }^{48}$ through the contrastive analysis of the languages and self-translation practices. Students returned to their own texts to try to achieve the communicative purpose in bilingual writing. In the perspective of bilingual writing, the native and foreign languages are susceptible for learning with specific objectives to improve performance. ${ }^{49,50}$ Table 4 shows that the students were aware of the narrative use of past tense, due to the limited number of problems in Spanish, as a mother tongue. Therefore, in the contrastive revision of the languages, for the most part, they simply solved the irregular verbal use in English of the present get and the past got. The improvement in English spelling was the result of the review and counseling support. The graphical accentuation in Spanish implied, mainly, to be aware that the past in Spanish requires, in many verbs, the graphic accent or tilde, for example, in $\mathrm{t} 14 \mathrm{~m}$ Me decepcioné versus Me decepcione ( $I$ got disappointed). In syntax, the greatest number of difficulties in English indicates an initial and gradual learning phase. This situation was solved in Spanish, due to the usage of simple structures in the past. Likewise, the data show a slight advance in the selections and lexical placements, mainly in English, as a result of the contrastive revision of words in a certain structural and contextual usage in both languages.

\section{Intentionality to express the inchoative meaning of state change}

The data in Table 5 show the difficulties in translating the inchoative semantic value, which corresponds to the beginning state change in bilingual versions. This meaning implies considering only the transition of the change or the process of the state in question..$^{32}$ In English, certain students expressed the semantic permanence state trait, for example, be depressed or be sick as equivalent to get depressed or get sick. In Spanish, the difficulty to express the inchoative meaning was predominant (13 of 25 students) when translating, for example, get depressed as "estar deprimido". Therefore, the problems faced by the students to express the inchoative meaning of state change are manifested in both languages in bilingual writing. Students needed to improve their knowledge of the foreign and mother language. Table 5 presents the students' performance in self-translation practices to express the inchoative semantic feature of state change in the lexical and morphological options in Spanish. We can notice the number of occurrences or appearances of the linguistic resource in the texts.

The data show that the lexical expressions (poner+expression of state: 20) and morphological expressions (parenthetical or suffixation: $15)$ were predominant, in relation to the trait of permanence through the predicative lexical resource (to be + expression of state: 13). The expression put + expression of state was consolidated as the most productive in self-translation. The combination of lexical and morphological resources enriched the possibilities of expression in Spanish. These results are favorable in the performance of selftranslation into Spanish in bilingual writing. However, the majority of students who expressed the permanence in health and emotional states (estar+expression state: 13) also used the inchoative lexical or morphological expression. Therefore, the presence of both semantic features in the translations (inchoative and permanence: 9) shows a partial progress in performance, since at times the students managed to solve the inchoative meaning, but also they hesitated when expressing the permanence one. We can appreciate this kind of performance in the 19f student text, because, for example, she solved the inchoative semantic trait in I got wet "me mojé", everything got worse "todo se puso peor", I got sick "me enfermé, I got sad and frustrated "me 
puse triste y frustado", but had complications in I got a cold "tenía frio", I got a fever "tenía fiebre", I got cold "estaba resfriado" and I got depressed and disappointed "estaba depresivo y decepcionado".

\section{9 f Second version}

English: Last Thursday it was raining on my way home. I got wet, I got a cold, and during the night everything got worse. I got sick, I got a fever, and I got pale and I got cold. Unfortunately on Saturday, I had a party with my friends. I got sad and frustrated, I got depressed and disappointed.
Spanish: El pasado jueves estaba lloviendo en mi camino a casa, me mojé, tenía frio, y durante la noche todo se puso peor me enfermé, tenía fiebre, me resfrié y frío, pero desafortunadamente el sábado, tenía una fiesta con mis amigos, me puse triste, frustrado y estaba depresivo y decepcionado.

This type of doubtful oscillations in self-translation indicates that achieving the bilingual expression of the inchoative trait for the state change meaning is a gradual process that involves the bilingual contrastive analysis. In self-translation, students can learn and improve the foreign and native language. ${ }^{51-54}$

Table 4 Resolution of difficulties in bilingual writing

\begin{tabular}{|c|c|c|c|c|}
\hline $\begin{array}{l}\text { Difficulties faced in the } \\
\text { bilingual expression }\end{array}$ & English first version & Spanish first version & $\begin{array}{l}\text { English second } \\
\text { version }\end{array}$ & Spanish second version \\
\hline $\begin{array}{l}\text { Past time tense for narrative } \\
\text { expression }\end{array}$ & $\begin{array}{l}18(1,2,3,4,5,6,7,10,12,13,15 \\
16,17,18,19,21,22,23)\end{array}$ & $2(1,17)$ & $\begin{array}{l}7(1,2,6,7,10 \\
12,13)\end{array}$ & I (17) \\
\hline Spelling & $\begin{array}{l}12(3,6,8,9,10,13,14,16,17,22 \\
23,25)\end{array}$ & I (2) & \multicolumn{2}{|l|}{$6(3,8,10,16,17,22)$} \\
\hline Accentuation & & \multicolumn{2}{|c|}{$\begin{array}{l}19(1,3,4,5,6,7,8,10,11,13,14,15,16,17,18 \\
19,20,22,24\end{array}$} & $6(5,8,10,11,17,18)$ \\
\hline Syntax, grammar & $\begin{array}{l}14(1,2,4,5,7,10,11,13,15,16,17 \\
18,22,25)\end{array}$ & $I(13)$ & \multicolumn{2}{|c|}{ II $(1,2,4,5,7,10,11,13,15,17,22)$} \\
\hline Lexical selections & $6(1,4$ I6, I8, 24, 25) & $3(6,17,24)$ & $4(4,16,18,25)$ & $2(6,17)$ \\
\hline $\begin{array}{l}\text { Inchoative meaning of state } \\
\text { change }\end{array}$ & $6(1,7,10,13,17,22)$ & $\begin{array}{l}13(1,8,9,10,12,13,14,15 \\
16,17,18,19,21)\end{array}$ & $\begin{array}{l}6(1,7,10,13 \\
17,22)\end{array}$ & $\begin{array}{l}13(1,8,9,10,12,13,14,15 \\
16,17,18,19,21)\end{array}$ \\
\hline
\end{tabular}

Table 5 Translation of the semantic feature of state change

Type of translation of the semantic feature of state ch
Inchoative through lexical resource
(poner + state expression)
Inchoative through parenthetical or suffixation morphology
Permanence through lexical resource
(be + state expression)
Both (inchoative y permanence)

\section{Conclusion}

The results of the study of the bilingual, English-Spanish, writing, using the verb get and its translation for physical health and emotional state changes allow the characterization of students' intentionality in their performances to try to express the inchoative, or beginning in transition, semantic state change and its verbal manifestation in both languages. The problems faced by the students with this meaning are manifested in the foreign and native languages in bilingual writing. The partial advance in the performance of the students involved the contrastive revision on bilingual linguistic resources of the intended meaning and the self-translation strategies in Spanish through the lexical and morphological options. In the translations in the first exercise and in the examples provided freely by the students about other uses of verbal phrases with the verb get, we can observe the difficulty to identify the inchoative feature of state change, for example, when translating get depressed, incorrectly as "being depressed". Therefore, students faced the need to recognize and avoid

\section{Occurrences in both versions}

$20(1,2,3,4,5,6,7,9,12,13,14,15,18,19,20,21,22,23,24,25)$

$15(1,2,3,4,6,7,11,14,15,18,19,20,22,23,24)$

$13(1,8,9,10,12,13,14,15,16,17,18,19,21)$

$9(1,9,12,13,14,15,18,19,21)$

confusion in the distinction of the beginning of change trait (get depressed: "depressed") and its permanence (be depressed: "to be depressed"). Likewise, the coexistence of these features in the texts shows the problems faced and the tendency to confuse the meanings and apply them in an undifferentiated way. In Spanish performance, the students had to decide how to translate the inchoative trait through lexical options, for example, get sad "ponerse triste" and the morphological ones, for example, get sad "en-trist-ecer-se", get cold "en-friar-se" and get upset "en-fadar-se").

On the other hand, the support of online consultation sources, dictionaries and translators did not favor the practice of selftranslation in bilingual writing because of the need to learn how to use these tools to their full potential, and in the case of online translator, take into account its limitations for grammatical and practical use of the language. In fact, online translator's queries require a reflexive use through knowledge and contextualized revision of the obtained translations. The general characterization of the texts shows a partial 
advance in the performance of the bilingual writing. In the second version the students improved the narrative use of past tense verbs in both languages, spelling, lexical selections and the graphic accentuation in Spanish. However, they were unable to solve the ambiguities in distinguishing and translating inchoative and permanence state change meaning in bilingual writing. Although in the second versions, the students advanced in the number of occurrences in the management of the inchoative value, they also expressed the trait of permanence, for that reason they did not manage to identify the distinction, for example, between get depressed "deprimirse" and be depressed "estar deprimido". Results exhibit greater difficulties in translation into Spanish, due to complications in the management of inchoative meaning in lexical options (poner + expression of state: to become $s a d$ ) and in morphological ones: parasynthetic (en-trist-ecer-se) and suffixation (deprimir-se). Likewise, the combination of inchoative and permanent traits in the translations is a fundamental evidence of the partial advancement in performance, since the students confused or didn't know the distinction between both meanings. These results indicate that in bilingual writing it is essential to pay attention, in a comprehensive manner, to the teaching of foreign and native language in an integrated perspective.

In lexical and morphological self-translation options into Spanish, the productivity of lexical manifestation (poner + state expression) shows the greatest partial advance in performance to distinguish the inchoative state change feature. By means of the lexical expression, the students were able to avoid, in Spanish, the possible difficulties implied by the parasynthetic morphological manifestations and suffixation. In this way, the students were able to partially distinguish the inchoative and permanent distinction, despite the confusion due to the combined use of both semantic features. The writing experience carried out in this study provides a proposal for characterization of performance in bilingual writing applied to practical situations, in this case, the use of the verb get in English and self-translation practices into Spanish to express health and emotional state changes. The students considered their knowledge and the contrastive analysis of the languages, they also experimented strategies to adjust the bilingual writing since they had different linguistic options in both languages.

The research proposal can be adapted in different educational environments, since bilingual writing is present in different situations and educational contexts. The emphasis on intentionality in performance allows us to take into consideration the partial advances of the students with the idea of improving the expression in a next version. The characterization of distinctive semantic features in verbal expressions is likely to focus on different aspects of interest in bilingual expression. Also, the proposal of analysis categories, centered on intentionality, favors the study of linguistics in the gradual learning processes of bilingual writing. Future research may address the study of other semantic features in bilingual expression with the verb get for other state changes manifestations and other verbal possibilities and repertories. The proposal provides expectations to characterize in detail the performance in the coexistence of translation resources and strategies as well as students' reflections on languages contrastive analysis and their impact on bilingual writing. In addition, the research contributes to the interest for promoting contextualized practices, with the purpose of improving bilingual writing in different contexts.

\section{Acknowledgements}

None.

\section{Conflict of interest}

The author declares there is no conflict of interest.

\section{References}

1. Duverger, Jean. L'enseignement en classe bilingue, París : Hachette. 2009.

2. Wenden, Anita. Helping language learners think about learning. ELT Journal An international journal for teachers of English to speakers of other languages. 1986;40(1):161-175.

3. Oxford, Rebecca. Language learning strategies: what every teacher should know. Boston: Heinle \& Heinle Publisher. 1990.

4. De Beugrande, Robert, Dressler, Wolfang. Introducción a la lingüística del texto. Barcelona: Ariel Lingüística. 1997.

5. Beuchot, Mauricio. Elementos esenciales de una hermenéutica analógica. Diánoia. 2015;60(74):127-145.

6. Francis, Norbert. El taller de escritura bilingüe en la documentación y rescate de las lenguas indígenas: un espacio de reflexión teórica. Lenguas en Contexto. 2011;7:3-10.

7. Francis, Norbert y Rainer Enrique Hamel. La redacción en dos lenguas: escritura y narrativa en tres escuelas bilingües del Valle del Mezquital, Revista Latinoamericana de Estudios Educativos. 1992;22(4):11-35.

8. Spicer-Escalante, María Luisa. Análisis lingüístico de la escritura bilingüe (español-inglés) de los hablantes de español como lengua hereditaria en los Estados Unidos. In Estudios de Lingüística Aplicada. 2007;45:63-80.

9. Fernández Guerra, Ana Belén. Polisemia y multifuncioanalidad de GET en inglés contemporáneo. Studies in English language and linguistics. 2001;3:23-68.

10. Fernández Guerra, Ana Belén. Notas en torno al verbo get y sus equivalentes en español. Revista de filología inglesa. 2001b;23:207-240.

11. Fernańdez Guerra, Ana Belén. Aspectos empíricos de la traducción artesana y automática del verbo "get". Castellón de la Plana: Universitat Jaume I. 2002.

12. Fernández Guerra, Ana Belén. Crossing Boundaries: The Translation of Cultural Referents in English and Spanish. Word and Text A Journal of Literary Studies and Linguistics. 2012;2(2):121-138.

13. McIntyre, Andrew. The Semantic and Syntactic Decomposition of get: An Interaction between verb meaning and particle placement, Journal of Semantics. 2005;22(4):401-438.

14. Mitkovska, Liljana, Bužarovska, Eleni. An Alternative Analysis of the English Get-Past Participle Constructions: Is Get All That Passive? Journal of English Linguistics. 2102;40(2):196-215.

15. Martínez Vera, Gabriel. Estructura sintáctica de las construcciones con verbos parasintéticos de los tipos a-...-ar y en-...-ar. Lexis. 2016;40:243292.

16. Martín Leralta S. La integración de la competencia estratégica en el currículo de lengua extranjera", ELUA. 2006;20(20):233-257.

17. Palapanidi K. La enseñanza de las estrategias compensatorias. Revista Nebrija de Lingüística Aplicada, 21. 2016.

18. Nida, Eugene. Contexts in translating. Ámsterdam/Filadelfia: John Benjamins, Benjamin Translation Library. 2001.

19. Bassnett, Susan. Writing and translating. In Bassnett, Susan y Peter Bush editors. The translator as writer. Londres: Continuum. 2006. pp. 172-182.

20. Romano Sued, Susana. Dilemas de la traducción. Políticas. Poéticas. Críticas. México: Universidad Nacional Autónoma de México. 2016.

21. Pegenaute, Luis. La traducción como herramienta didáctica. Contextos. 1996;14(27-28):107-112. 
22. Nord, Christiane. Text Analysis in Translation: Theory, Methodology and Didactic Application of a Model for Translation-Oriented Text Analysis, Amsterdam: Rodopi. 1991

23. Popovič, Anton. Dictionary for the Analysis of Literary Translation. Edmonton: Department of Comparative Literature-University of Alberta. 1976.

24. Cocco, Simona. Lost in (Self-) Translation? Rifl essioni sull'autotraduzione. In Simona Cocco, Massimes Dell'Utri, Simoneta Falchi y Stephen Lo White editors. Unnali della Facoltà di Lingue e Letterature Di Sassari. Lost in Translation. Testi e culture allo specchio. Sassari, Facoltà di Lingue e Litterature Straniere-Università degli Studi di Sassari. 2009 ;6:103-118.

25. Dasilva, Xosé Manuel. La opacidad de la autotraducción entre lenguas asimétricas. In TRANS. Revista de Traductología. 2015;19(2):171-182.

26. Jung, Verena. English-German Self-Translation of Academic Texts and its Relevance for Translation Theory and Practice. Oxford: Peter Lang. 2002

27. Casado Antoniazzi, María Inés. Verbs in English and their Spanish counterparts. Didáctica Lengua y Literatura. 2010;22:69-92.

28. Molina Plaza, Silvia. Contrastive Analysis of Stretched Collocations with Get and Take: Their use and Pedagogical Implications. Journal of Social Sciences. 2015;11(3):179-193.

29. Sánchez Bartomeu, Raquel. Syntactic mismatches between English and Spanish: A descriptive analysis and classification. Tesis doctoral: Universidad Autónoma de Barcelona. 2015.

30. Rudnicki, Mikołaj. Análisis contrastivo inglés-español de los verbos de cambio. Tesis de maestría. Uniwersytet Adama Mickiewicza w Poznaniu Wydział Neofilologii Instytut Filologgi Romańskiej. 2017

31. Sánchez Rufat A. Rasgos de la competencia léxica del verbo. Revista Nebrija de Lingüistica Aplicada 17. 2014.

32. Lloyd, Paul M. Del latín al español. Fonología y morfología históricas de la lengua española. Versión española de Adelino Álvarez Rodríguez. Madrid: Gredos. 1993.

33. Koontz-Garboden, Andrew. Aspectual coercion and the typology of change of state predicates. Journal of Linguistics. 2007;43:115-152.

34. Lavale Ortiz, Ruth María. Los verbos denominales de cambio de estado experiencial: consideraciones sintáctico-semánticas. Revista internacional de lingüística iberoamericana. 2013;1 (22):29-46.

35. Saldívar Arreola Rafael, Rábago Tánori Álvaro, Lozano Bachioqui, et al. La traducción de verbos de movimiento del inglés al español. Una aplicación práctica de la semántica componencial en la formación de traductores. Forma y Función, Universidad Nacional de Colombia Bogóta, Colombia. 2015;28(1):99-115.

36. Munguía Zatarín, Irma, Munguía Zatarán, Martha Elena \& Rocha Romero, Gilda 2002. Gramática de la lengua española. México: Larouse. 2005.

37. Fabregas, Antonio, Rafael Marín, and Louise McNally. From Psych Verbs to Nouns. En Demonte, et al., editors. Telicity and change of state in natural languages: implications for event structure. Oxford: Oxford University Press. 2012. p. 162-284.
38. Consigny Antoine. The polysemy (?) of phrasal verbs in English. Word. 2006;57(1):1-25.

39. Marín Arrese, Juana I. Conceptualization of events, semantic relations between constructions and topology: A catastrophe theoretic study of get and be. Journal of English studies. 1999;1: 97-117.

40. Cifuentes Honrubia, José Luis. Spanish deadjectival verbs and argument structure. In Cifuentes Honrubia, José Luis et al., editors. Spanish word formation and lexical creation. Philadelphia: John Benjamins Publishing Company. 2011. p. 65-106.

41. ENP UNAM. Programas de estudio del bachillerato. Inglés, lengua extranjera. Escuela Nacional Preparatoria. México: UNAM. 1996.

42. Gass Susan M, Alison Mackey. Data Elicitation for Second and Foreign Language Research. Mahwah: Lawrence Erlbaum Associates. 2007.

43. Hyland, Ken. Methods and methodologies in second language writing research. System. 2016;59:116-125.

44. Hernández Rodríguez, Everaldo Reyes Galicia. Recomendación de textos en inglés y en español. Manual de recursos para la redacción bilingüe. 2015

45. Petrucă, Irina. Self-translation, Communication Bridge between cultures. In Iulian Boldea (coord.), Studies on Literature, Discourse and Multicultural Dialogue. Section: Language and Discourse, Târgu Mureş: Arhipelag XXI. 2013. p. 759-762.

46. Grutman Rainer, Trish Van Bolderen. Self-translation. In Bermann, Sandra et al., editors. A Companion to Translation Studies West Sussex, Wiley-Blackwell. 2014;323-332.

47. Zacarías Ponce de León, Ramón. Rivalidad entre esquemas de formación de palabras. México: Universidad Nacional Autónoma de México. 2016.

48. Bausela Herreras, Esperanza. Relación entre autorregulación y autoconocimiento de la escritura con la coherencia y productividad de un texto. Cuestiones pedagógicas. 2007;18:257-270.

49. Duverger, Jean coord. Enseignement bilingue. Le professeur de "discipline non linguistique”: Statuts, fonctions, pratiques pédagogiques. París, Association pour le Développement de l'Enseignement Bi/plurilingue. 2011

50. Geiger-Jaillet, Anemone, Gerald Schlemminger y, Christine Le Pape Racine. Enseigner une discipline dans une autre langue: méthodologie et pratiques professionnelles, Frankfurt: Peter Lang. 2011.

51. Fleisher, Nicholas. The origin of passive get. English Language and Linguistics. 2006;10(2):225-252.

52. Freeman, Yvonne S, Daniel E. Freeman. Teaching Reading and Writing in Spanish and English in Bilingual and Dual Language Classrooms. Portsmouth: Heinemann. 2006.

53. González Martínez, Ana Gabriela; Maldonado Soto, et al. Quedadar: Cambio de estado y locación en el español de México. Forma y Función. 2017;30(1):9-30

54. Hernández Rodríguez, Ernesto. Intencionalidad y desempeño en la redacción bilingüe, español-inglés, de reseñas bibliográficas en bachillerato. Signos Lingüísticos. 2015;9(21/22):36-69. 